\title{
Markets, Money and Ideology
}

\author{
Simon Mohun \\ Department of Economics, \\ Queen Mary and Westfield College, \\ Mile End Road, \\ London E1 4NS. \\ e-mail: S.Mohun@qmw.ac.uk \\ telephone: $+44-171-975-5089$
}

March 1999

Abstract: Marx's critique of Hegel is used to derive a demarcation criterion that sharply separates scientific knowledge from ideology, and interprets Hegelian methodology as fundamentally ideological. Economic theory is considered according to this demarcation criterion, and the paper argues that economic science too easily becomes economic ideology. One reason for this tendency towards slippage is the dominance of money relations in contemporary society. For the labour theory of value in Marx has a theory of money whose structure is identical to Hegelian logic, and an antipathy to a scientific approach is thereby grounded in everyday life.

JEL Classification: A14, B41 


\section{Introduction*}

Contemporary economic theory begins with axioms and assumptions and uses a deductivist methodology to arrive at conclusions; the goal is to provide explanations for prevailing patterns of economic activity (or predictions for those patterns given some parameter change). Recent years have seen a variety of criticisms of this approach. Lawson (1997) in particular has argued that where axioms and assumptions are fictitious (in the sense of having negligible empirical relevance), the conclusions of deductivist models can only have relevance to the structure of those models, for the models themselves can bear no relation to economic reality. He further argues that the methodological strategy of deductivism requires a foundation of event regularities, and these are conspicuous by their absence in economics, so that more realistic axioms and assumptions within such a methodology would not be an improvement.

The concern of this paper is different, although in some aspects related. Instead of a transcendental realist approach, the paper explores Marx's critique of the attempt by German idealism to resolve the difficulties of Kantian dualism. In doing so, the paper proposes a sharp demarcation between science and ideology, and considers modern economic theory in these terms. The paper then suggests a reason why modern economics slips so easily from science to ideology.

Ideology is in general concerned with people's beliefs. This paper is situated within the intellectual tradition that relates subjective beliefs to people's objective conditions of existence. Thus it is presumed that there is a difference between a person's objective conditions of existence and her subjective experience of those conditions, and that an account of the former can meaningfully be given. Hence a theory of ideology has to explain (among other things) this difference. This

\footnotetext{
* I am grateful for critical comments on earlier drafts of this paper from Riccardo Bellofiore, Ben Fine, Duncan Foley, Susan Himmelweit, John Rosenthal, and Michael Williams. The usual disclaimer applies.
} 
immediately implies that there is a set of epistemological issues with respect to ideology, which concern the characterisation of 'knowledge' from which vantage-point the 'ideological' is identified. 1

The existence of a difference between objective conditions of existence and subjective experience of them implies that the terms 'objective' and 'subjective' can be satisfactorily defined. In the language of the nineteenth century, Marx expressed the contrast between objective and subjective in terms of a contrast between a materialist and an idealist approach to social reality. Such a contrast founded the claim that ideology was 'false consciousness'. ${ }^{2}$ However, this raised more problems than it solved, since it implied a state of 'true' consciousness, yet said nothing about how such a state was to be attained. Politically, it left the way open for those who claimed privileged access to 'knowledge' to form 'vanguard' political parties in the pursuit of state power. Such approaches have hardly been crowned with success. ${ }^{3}$

This is one reason why approaches within the Marxist tradition to the analysis of ideology have in recent years been heavily criticised. ${ }^{4}$ Such criticisms (deriving in large part from the work of Foucault) are generally concerned with subverting notions of economic determinism and replacing them with a discourse theory of knowledge, truth and power. Discourses in and of themselves are

1 This 'critical' approach is sometimes contrasted with a more 'neutral' one that sees ideologies as 'belonging' to particular groups.

2 Not all materialist analyses are necessarily 'true'; Marx's point was rather that all idealist analyses are 'false'. While a materialist approach is necessary for a true account, an idealist approach is sufficient for a false one.

3 Explanation of failure in terms of the vanguard 'betraying' its followers has long appeared an immunizing stratagem.

4 See, for example, Barrett 1991. 
neither true nor false, but within a discourse regimes of truth can be identified with historically specific relations between power and knowledge, those relations producing the effects of truth in historically specific ways. The 'politics of truth' is thereby set against the traditional epistemological notion of the 'economics of untruth'.5

However, what motivates this paper is not that epistemological accounts of ideology have in general been vitiated by economic determinism. It is rather that standard versions of these accounts have not paid sufficient attention to the 'economic'. In this paper the 'economic' is not just a generalised notion summarising material conditions of existence; it has a much more specific content, to do with the pervasiveness of money relations in contemporary society. Money is the form through which social validation is bestowed upon commodity outputs, and as such is the general form of appearance of 'value'. Production for the market and its associated monetary relations certainly preceded capitalism, but it is only with capitalism that market phenomena penetrate all areas of social existence. An adequate theory of the forms that 'value' takes is therefore in part a theory of the appearances of capitalism. As such, the theory of money provides the basis for an epistemological theory of ideology.

It is true that one part of the Marxian tradition has long seen this basis in the reifications of commodity fetishism. A standard argument within this tradition is that failure to recognise these reifications means that tendencies towards universality within particular, historically determined forms are misconceived as tendencies towards an atemporal universality. The consequence then is that a particular social order is misinterpreted as the universal natural order of things, a slippage characteristic of ideological rationalisations of (and for) the status quo. Such slippage is a logic of hypostatization. The logic of hypostatization in Hegel and Marx was examined by Colletti (1972, 1973, 1975a, 1975b), and more recently was treated at length by Rosenthal (1998), but has

5 The phrases are Foucault's, cited by Barrett (1991, p.vii). Note that McCloskey's work on rhetoric (McCloskey 1986, 1994) has some points of contact with this literature. 
otherwise been surprisingly ignored. Most attention to Colletti has focused on his philosophical treatment of the dialectic, and his advocacy of a Kantian rather than an Hegelian approach to contradiction. But virtually no attention has been paid to a different but related part of his argument, that

"the processes of hypostatization, the hypostatization of the abstract, the inversion of subject and predicate, far from being in Marx's eyes modes of Hegel's logic that were defective in reflecting reality, were in fact processes that he located ... in the structure and mode of functioning of capitalist society itself." (Colletti 1975b, p.20)

This process of hypostatization is not only a logic, but a real process; money is a hypostatization of the concrete and particular as the abstract and general, and part of the real effects of such a hypostatization is the reifications of commodity fetishism. Hence the paper explores the connections between the logics of money and of ideology.

The first section of the paper defines a materialist ontology and discusses what sort of epistemology might be compatible with that definition. In doing so, it outlines an interpretation of Marx's critique of German idealism, a critique, that is, of the process of inversion whereby Hegel's philosophy hypostatises the abstract in the concrete. This process of inversion is then used to define a criterion of demarcation between science and ideology. The second section considers contemporary economic theory in terms of this opposition. The third section briefly outlines some aspects of the labour theory of value in Marx, and considers the phenomena of commodity fetishism in terms of the process of inversion. The next section argues that commodity fetishism is not a simple intellectual mistake because its inversions derive from the logic of the money-form of value. The paper concludes with the assertion that not only is the logical structure of ideology different from the logical structure of scientific activity; the logical structure of ideology is also identical to that of the money-form of value. The underlying conjecture of the paper is that this identity might go some way towards explaining why the economic analysis of money and markets is so frequently ideological rather than scientific. 


\section{Thought, Reality and Hypostatization}

\section{i. Materialism and Idealism}

It is obvious that the world can only be known through thought, and that to think is to interpret, so that mental, interpretative activity is the only process through which the objective world can be known. To assert the existence of an objective world in this manner is already to assert a materialist standpoint. If objective conditions of existence and the subjective experience of those conditions are not the same, then a materialist explanation has to show how the appearances of the capitalist world are in some sense both different from and at the same time derived from an underlying reality. This requires first a more careful specification of 'materialist'. I define as 'materialist' the ontological claim that some things exist quite independently of all interpretative activity. But an ontologically materialist stance immediately raises the epistemological question of how such intrinsic unobservables can be known. How, that is, can an ontological materialism be combined with an epistemology that is not idealist?

Any materialist analysis has to take as its starting point the sensible-empirical world: theory is constructed out of what is revealed by sense-impressions. One issue is whether such senseimpressions allow inference of the existence of those objects of knowledge that exist independently of all interpretative mental activity. The difficulty with such transcendental arguments is that logical inference is a mental activity. Hence while such an approach can be consistent with the ontological materialist claim that there are some objects whose existence is independent of mental activity, that consistency can only be achieved by assertion. For all knowledge must always depend upon mental activity, and at face value this appears to deny the Kantian dualism that there are two sources of knowledge, thought and reality, by dissolving reality into thought and thereby rendering the ontological materialist claim contentless. 
This example illustrates what has often been seen as a difficulty: a theory that claims to be materialist is irredeemably dualist, asserting first, that at least some reality exists independently of sense-impressions, and second, that all theory, including materialist theory, proceeds by abstraction, so that real material relationships are theorised as relationships in the mind between formal abstract concepts. Such dualism can only be overcome by showing either that thought is entirely a derivate of material reality, or, conversely, that reality is entirely a derivate of thought.

The simplest approach to the first route is through a 'reflection' theory of perception in which what is perceived via sense-impressions directly and immediately reflects material reality. The difficulty with this is that it substitutes for ontological materialism a version of empiricism (all that exists is accessible to sense-impressions, and nothing else exists). Not only does this runs counter to the idea that how things appear and how they are might be different and therefore require explanation; its denial of interpretative activity also runs counter to the sheer range and variety of human emotion and experience in apparently similar material conditions. Consequently, it is the second route that is more relevant here.

To overcome dualism in this direction is to follow the German idealist tradition deriving from Kant (rather than the British empiricist tradition). Formal abstract concepts are treated as realising themselves in material objects, and the relationship of material reality to thought is transformed into the relationship of thought to itself. Thought is no longer constrained by a finite empirical world, and indeed denies the reality of the latter as anything other than the objectification of thought. Then it becomes possible to argue that the dependence of thought upon reality is only a misleading appearance, because reality is in fact created by thought, as its manifestation. On this basis, Hegel in particular constructed a dialectical process whereby thought alienates itself from itself by objectifying itself in material objects; in so doing it creates a barrier to its own further development which it has to overcome. And this dialectic is teleological because it is a process whereby thought eventually comes to a self-knowledge of itself as absolute divinity (mind is Mind 
and Mind is God).

The challenge for ontological materialism is how to retain some content in the face of this epistemological idealism. Marx's own writings did not address these issues (at least directly). His early writings were written in the cultural context of German idealism's reaction to Kant, which retained epistemological idealism and abandoned ontological materialism. And once the independence of the object of thought (the material world) from thought itself was denied, then philosophy became theology, and the justification of Christianity, or at least some sort of similar theism, became a dominating theme. Marx's early writings are dominated by his reaction to this tradition. But while this mid-nineteenth century milieu is now some distance from contemporary concerns, it is necessary to outline some of the issues raised in order to understand their continuing relevance.

Marx argued that Hegel's arguments were quite mistaken, and in two ways. First was the way in which Hegel reduced material reality to thought. Since reality is finite whereas thought is not, material reality has to be interpreted as what it is not, in terms of its potential to transcend finitude. Marx called this 'negative' aspect of Hegel's dialectic his "uncritical idealism". 6 Second, at any moment of time, thought is hypostatising itself as material reality, so that any reality, no matter what it is, has a reason for its existence. ${ }^{7}$ Marx called this 'positive' aspect of Hegel's dialectic his "uncritical positivism". 8 Thus for Marx, what Hegel did was first, to reduce reality to thought, and then second, to interpret reality as the hypostatization of thought. To a materialist, this relation between reality and theorising about reality is inverted. The infinite activity of 'thinking' is a property of finite 'thinkers'; the person who thinks is the subject, and the activity of thinking is the

6 Economic and Philosophical Manuscripts of 1844. MECW 3, p.332.

7 Synonyms for 'hypostatising' include objectifying, materialising, substantifying and reifying.

8 Ibid. 
predicate. But Hegel transformed 'thinking' into a self-sufficient activity, which is manifested in 'thinkers'. The predicate becomes the subject, and the subject the predicate. Thought, which is the property or predicate of material being, becomes the subject, and the subject, which is material being in a material world, becomes the object of thought. 9

This inversion of subject and predicate can, however, only be recognised by a process of thinking, or theorising. The materialist assertion that reality conditions and determines thought and that German idealism inverted subject and predicate is itself an assertion of theory and its associated abstractions. Therefore a distinction must be drawn between materialist and idealist abstractions. Hegel's abstractions are idealist: mental generalisations, totalisations, whose dialectical development of estrangement and supercession is a process of increasing self-awareness of themselves as totalisations. This is a purely logical process, in which material reality can only appear as a process of hypostatization of the abstraction with which the theory began. Hegel's derivation of the concrete from the abstract is one whereby the concrete (and finite) becomes the manifestation or appearance-form of the abstract (and universal), and the material world is thereby constructed out of thought. In a materialist project, the issue is different: not how does thought construct reality, but rather how does the theorist comes to knowledge of an independent material reality. In this, the recognition of the 'otherness' of material reality from theorising about it is critical, for theory becomes knowledge, in however preliminary and circumspect a form, only through its ability to confront the empirical (however theorised the latter is). Thus Marx commented in his notebooks on value theory that he would need

"to correct the idealist manner of the presentation, which makes it seem as if it were merely a matter of conceptual determinations and of the dialectic of these concepts. "(Grundrisse, p.151.)

And in the 1873 Postface to the second edition of Capital I, he remarked that

9 See for example Contribution to the Critique of Hegel's Philosophy of Law. MECW 3, pp.23-4. 
"the method of presentation must differ in form from that of inquiry. The latter has to appropriate the material in detail, to analyze its different forms of development and to track down their inner connection. Only after this work has been done can the real movement be appropriately presented. If this is done successfully, if the life of the subject-matter is now reflected back in the ideas, then it may appear as if we have before us an a priori construction.” (Capital I, p.102.)

However, there is a sense in which reality is created by thought. For there is a difference between the materiality which constitutes the physical world, and that which constitutes social reality. Human history depends upon ideas in a way in which the structure of the nucleus of an atom does not. In the nexus of social relationships which constitutes human reality, notions such as justice and injustice, liberty and tyranny, equality and inequality are sufficiently fundamental that social reality could in many ways be said to be constitutive of such ideas. ${ }^{10}$ The question then is where these ideas come from.

A general materialist answer is that they arise out of practical participation in social relationships and in particular out of practical participation in the market. Materialist abstractions are not mental generalisations; they are one-sided aspects or properties of the concrete, the creation of whose commonality (which enables meaningful abstraction) are real processes. The process of exchange, for example, is a real process that derives the money-form out of the property that all commodities are produced for exchange. Multilateral exchange requires something to represent what different production processes have in common, and then all trace of what qualitatively differentiates such production processes is absorbed into quantitative differences of amounts of money. Thus the process of exchange as a practical activity abstracts from qualitative heterogeneity to generate a quantitative homogeneity. From this perspective, the mental activity creating the labour theory of

10 Michael Williams in particular has emphasized this in comments on an earlier version of this paper. 
value arose out of reflection on the spread of cottage industry and the growth of markets in eighteenth century England. The abstraction 'alienation' is a real process in a society in which the direct producers have been deprived of access to either the means of production or the products of their labour save through the market. The abstraction 'the labour market' is derived from a set of particular historical circumstances whose net effect was eventually to drive the peasantry off the land and into the new towns as a landless proletariat. And the abstraction 'unemployment' required that urbanisation as a pre-condition. In sum, materialist abstractions are generated by real processes, and are subsequently reflected in thought as the mental generalisations of theory. Hence materialist abstractions depend on the ontological 'otherness' of the material world, and in this they are qualitatively different from the idealist abstractions of pure thought.

\section{ii. Science and Ideology}

One consequence of a procedure that reduces material reality to thought, and then interprets any instance of reality as hypostatised thought, is that it is always self-confirming. It is true that in Hegel this self-confirmation is complex; via a process of successively superseded hypostatizations of thought, the teleology of the dialectic ensures the ultimate self-confirmation of thought in the grandest possible sense. Self-confirmation does not however have to be wedded to such a grand

system. Indeed, self-confirmation is in general one of the characteristics of an ideological conception of reality. For the defining characteristic of ideological thought, be it racist, religious, sexist or nationalist, is to take as its starting-point some generality, which is then materialised in some concrete particular. As such, this procedure is 'essentialist'. Individual observations (whether real or imagined) are inductively generalised into a universal proposition, or 'essence', which is then used to define the nature of the individual instances. An assertion of what things are becomes a substitute for their explanation, and definitions thereby replace the confrontation of theory with evidence. In this respect, the whole Hegelian system is an example of an ideology.

A scientific approach is different, not in degree but in principle. For while it is notoriously hard to 
produce a definition of science which covers all scientific activity, nevertheless a scientific approach is the opposite of self-confirmatory: science cannot progress unless experiments can be devised which can verify (or more weakly at least be consistent with) or falsify the predictions of theory. The evidence with which to confront a theory is different from the theory itself, and without such a materialist ontology science becomes impossible.

In one respect, however, it could be argued that scientific thought is apparently similar to ideology. Universal laws (regularities in nature) are never testable without an accompanying set of auxiliary hypotheses, and so it is always problematic to interpret precisely what is being tested by an experiment. One version of the Duhem-Quine hypothesis is that observations are always theoryladen, so that any hypothesis cannot be regarded as being conclusively refuted by some contrary evidence, and this imports a degree of convention into scientific procedures. Nevertheless, while science proceeds through the formulation of general laws and interprets particular empirical phenomena in terms of those laws, it is possible for empirical phenomena to contradict the general law. Such results might be ignored for a period, but their cumulation eventually leads to substantive revision of the general law. Science is then different from ideology, for the empirical instance is treated as different from the general law. It might confirm it, but it has a separate existence from it. It does not matter for this argument whether a realist or an instrumentalist approach is adopted. ${ }^{11}$ In either case, the empirical instance has a different status from the explanatory or predictive theory. In sum, whether in the natural or social sciences, because the real world is something other than the materialisation of theory, the assertions of theory have in some sense to be testable, and therefore capable of refutation.

11 Realists seek to discover truths about the world, explanations for why things are as they are; instrumentalists are more skeptical of explanations relying on unobservables, and argue that scientific activity is better devoted to establishing predictions (no commitment being thereby implied about the epistemological status of unobservables). 


\section{Ideology, Science and Economics}

Against this background, how does economics fare? Much intellectual effort has gone into the construction of models, and in order to obtain particular results, economic models have to be drastically simplified. In itself, this is neither exceptionable nor even remarkable. Here I focus on two such simplifications, aggregation across goods and aggregation across agents. Both of these simplifications are known to be problematic.

Consider first aggregation across goods. Since the work of Leontief in the late 1940s, it has been known that in general the theoretical condition for aggregation such that the aggregate behaves as though it were a single good is highly restrictive. ${ }^{12}$ One way around this is to presume a one good world, but the number of interesting questions that can be asked of such a model is limited. A second procedure is to restrict the model to steady state growth; then there exists a set of intertemporal prices such that all own rates of return are equal, and at the rate of interest a chain index of capital for example can be constructed. But there are still difficulties. For suppose there are two price vectors, each satisfying equality of all own rates of return, that support some given efficient output plan; then so will any non-negative linear combination of these price vectors. Yet there is no reason why such a linear combination across steady states will also have all own rates of return equal, and there is therefore no good economic reason to presume it. ${ }^{13}$ The literature,

12 To replace a vector of quantities of some set of commodities with a scalar which completely summarizes that vector requires that the marginal rate of substitution between any two of the commodities being aggregated is independent of the quantity of any commodity outside of the set of those being aggregated.

13 This was not clearly stated during the 1960 s' capital controversies, but see Bliss (1975, ch. 710) and Dixit (1977). 
though, is replete with the use of aggregate variables whose aggregation lacks any theoretical rationale. 14

Secondly, consider aggregation across agents. In consumer theory, the explanation of individual consumer demand is sought in constrained utility maximisation on the basis of given preferences and endowments. This should be tested by the empirical observation of the way in which people behave in contemporary society. But it isn't. For the demand data available is not typically that of the household, but is rather that of an aggregate of households, and that aggregate cannot be treated as representative of its individual components (unless very strong and highly unrealistic assumptions are made about the distribution of preferences or income). When individual excess demand functions are aggregated, then the aggregate excess demand function will be continuous, homogeneous of degree zero in prices and (everyone's) income, and (given local non-satiation of all consumers) satisfy Walras' Law. But no other properties will in general carry over. In particular, the aggregate function may not satisfy the Weak Axiom of Revealed Preference. Further, rather strong assumptions have to be imposed upon the aggregate function to ensure uniqueness and stability, without which comparative statics arguments make little sense. ${ }^{15}$ Accordingly, the only way to combine a rigorous analysis based on individual maximisation with 'rationality' which yields uniqueness and stability is to presume a 'representative agent'. But not only does such a modelling strategy pose some difficulty in even thinking about such phenomena as asymmetric information, a stock market, and the distributional effects of government policy. It is also that there is some difficulty in conceptualising economic activity and trade at all. Kirman (1992) critically surveys the difficulties of using a 'representative agent' argument to circumvent aggregation difficulties, and concludes,

14 In particular, the use of aggregate production functions widely ignores the outcome of the 1960s' capital controversies.

15 For a survey, see Mas-Colell, Whinston and Green (1995, ch. 4). 
"the fact that behavior at the macroeconomic level exhibits regularities does not mean that it is useful or appropriate to treat the economy as a maximizing representative individual." (Kirman, 1992, p.134)

Notwithstanding these strictures, the common justification for ignoring these difficulties is indeed that aggregate models with their nominal rigidities and their implications for short run movements in output work rather well empirically, and that therefore an opportunistic approach to model construction, even if only loosely theoretically justified, is reasonable (Solow 1997, Blanchard 1997). The counter-argument is that, while a model with rigidities might account for observed time series, those rigidities have to be theoretically explained, and that theoretical explanation has to be situated in the Walrasian tradition of general equilibrium in which observed movements in quantities are analysed as an optimising response to observed movements in prices (Lucas 1977). ${ }^{16}$ High theory in the Walrasian tradition therefore dispenses with at least some aggregation, but the scientific results are disappointing. ${ }^{17}$ First, because uniqueness is problematic, and out-ofequilibrium behaviour not well specified, the method of comparative statics lacks a secure rationale. Secondly, the theory has no real handle on the existence of money and hence on problems of aggregate demand. Thirdly, intertemporal analysis, which attaches a date, and uncertainty, which attaches a state of the world, to each commodity, sits oddly with the empirical paucity of futures markets. And fourthly, modelling time in a finite-dimensional commodity model is awkward, because it appears to imply that at some date the economy will come to an end. Because of this, much recent work has switched attention to infinite horizon (overlapping generations) models. In such models, either saddle point stability is just assumed, or some additional hypothesis is introduced, additional that is to the basic assumptions of the theory and the

\footnotetext{
16 Kirman disagrees, advocating instead an approach in which heterogeneous individuals engage in heterogeneous activities and interact directly with one another but in a restricted subset of the economy. See also footnote 18 below.
} 
market-clearing requirement, which leads to the result. Because ruling out complex dynamics requires strong assumptions, the saddle-point literature is characterised by special rather than by general results. Indeed, in these infinite commodity space models, equilibrium paths might be indeterminate (because non-unique), the 'fundamental' theorems of welfare economics do not hold, and 'sunspot' equilibria might exist. ${ }^{18}$ In these circumstances, it is not obvious that the vision that sees prices as determined by supply and demand (whatever the level of aggregation) is a helpful one. 19

These scientific difficulties rarely find an acknowledgement in textbook treatments. In elementary textbooks, simplified theories are presented whose justification is sought not in confrontation with a real world, but in terms of an axiomatic rationalism. The usual approach is to assert that it is a characteristic of human nature to be acquisitive, but that scarcity is pervasive because wants are unlimited relative to the resources available to satisfy them; hence choices must be made, and economics is the study of these choices and their consequences. ${ }^{20}$ Such an axiomatic procedure is

17 For an informal survey, on which the remainder of this paragraph draws, see Foley (1990).

18 For a survey, see Blanchard and Fischer (1989, ch.5). An earlier account of the Walrasian framework which rehearses many of the conceptual difficulties with equilibrium, uniqueness and stability is Bliss (1975, ch.2).

19 The profession is not however monolithic, and recent years have seen a something of a switch in emphasis away from the Walrasian perspective and towards one of prices as being determined by information. In part influenced by developments in financial economics, current prices, at least for durables, are seen as determined by the transversality conditions concerning flows of information about long run valuation, the (possibly asymmetric) relation of agents to these flows, and their forecasts of them. See Stiglitz (1994) for a recent survey.

20 See for example Parkin (1990, p.9). It is not obvious why such an account is economics; but partly it is this sort of approach that accounts for the imperialism of economics with respect to the methods and subject matter of the other social sciences. 
valid for all times and all places, and contemporary behaviour is interpreted as just a specific instance. In this manner, the specificity of contemporary society is universalised, and the present is then seen as a particular realisation of the universal. But this is an ideological rather than a scientific approach. Something specific in contemporary society is universalised (rendering detailed historical analysis of behaviour and of institutions unnecessary). All concrete instances, no matter how historically different, are then treated as hypostatizations of the same universal. Thus wage-labour becomes labour; capital becomes the instruments of production; the labour process becomes a production function; acquisitive behaviour becomes human nature, and so on.

Sometimes what is universalised is not something specific in contemporary society, but rather something that is alleged to be specific, for no better reason than it conforms to a first principles axiomatic structure. 'Rational expectations' is a good example of this, eliciting some trenchant comments from Blinder:

"Direct empirical evidence on individual behaviour is difficult - some would say impossible - to come by. But what little we know from experiments by psychologists ... does not suggest that homo sapiens behaves like homo economicus. ... Inconsistent choices are common. People put too much weight on what has happened to them and their friends and too little on statistical evidence. Framing of the question matters. The von NeumannMorgenstern axioms are routinely violated. It is remarkable how little impact this evidence has had on modern economics. Is that scientific detachment or religious zealotry?" (Blinder, 1987, p.135.) $)^{21}$

If contrary evidence is persistently ignored, then one of two (not mutually exclusive) possibilities obtains. Either economics is the study of models whose logic is investigated but whose relation to

21 See also Tversky et al. (1990). 
the world is not. ${ }^{22}$ Or economics is the study of models which are hypostatised as the world in which we live, in which case economics becomes an essentialist ideology, condemned to fail in any attempt to achieve historical specificity in its analysis. 23

More advanced texts generally ignore the issue of foundational justification, although Kreps is a recent exception. ${ }^{24} \mathrm{He}$ is emphatic that theory should be testable, and tested, empirically, and he argues that where it is not, theory "may still lead to better understanding, through a process that combines casual empiricism and intuition" (Kreps, 1990, p.7). In similar vein Hahn comments (after remarking that consumer theory cannot be falsified by the study of aggregate demand functions),

"it is neither surprising nor scandalous that a very old theory has no very firm empirical basis. Yet it would be odd to claim that it does not aid understanding." (Hahn 1984, p.5)

The difficulty is that 'casual empiricism and intuition' do not occur in a social vacuum, and the slide from a scientific approach to an ideological one is all too easy. Why this might be is concern of the remainder of this paper.

To introduce this, I return to the theme of the previous section. Marx's analysis of Hegel's inversion of subject and predicate was written in 1843 and 1844. This was not an analysis in which a potentially subversive, because negative, dialectic was contingently attached to a glorification of

22 It could be argued that calibration tests such a relation, but the extent to which calibration amounts to an investigation of the relationships between neoclassical stochastic growth models and the real world is currently a matter of some controversy. See for example Sims (1996).

23 Because such essentialism is empty of specific historical content, arbitrary auxiliary hypotheses have to be added, which comes close to the practice, so condemned by Popperians, of generating immunizing stratagems.

24 Bliss (1975, passim but especially chs. 2 and 15) also has much of interest in terms of foundational justification. 
the Prussian status quo. ${ }^{25}$ It was rather that Hegel inverted subject and predicate first by dissolving concrete reality into abstract thought and then by hypostatising it as the empirical world. The inversion comprising these two processes was at the heart of Hegel's dialectic. Then almost immediately, in the middle 1840s, Marx abandoned philosophy for economics. As a materialist whose intellectual origins lay in German idealism, he had come to realise that there was a very close relation between the structure of Hegel's logic and the economic structure of capitalist reality itself. His argument was not just that Hegel's reduction of reality to thought had to be inverted by a materialism that sees thought as grounded in and determined by an independent material reality. For that would be to ignore the role of hypostatization in Hegel's idealism. What Marx came to realise was that the Hegelian dialectic's peculiar combination of 'uncritical idealism' and 'uncritical positivism', its reduction of the world to thought and its treatment of the real as the hypostatization of that thought, was a theoretical approach which exactly mirrored the real money relations of generalised commodity production in contemporary capitalism. That is, the abstraction from the concrete and then the hypostatization of that abstract as the concrete in Hegel's dialectic is also the logic of money in capitalist society. ${ }^{26}$ It was for this reason that Hegel's dialectic was a useful methodological tool for a philosopher turned economist to use in understanding the workings of a capitalist economy. To pursue this theme further requires a brief outline of some aspects of the labour theory of value in Marx.

25 Marx's approach was not published until 1927 and 1932. By then the canonical treatment of Hegel in the Marxian tradition had been laid down by Engels in his Anti-Dühring (1878), in which he distinguished between the revolutionary nature of Hegel's dialectic, and the conservative nature of the Hegelian system, and argued for the detachment of the former from the latter. In terms of Marx's 1843/4 analysis, this was nonsensical. Hegel's dialectic was intrinsic to his system as a whole.

26 Whether this was just a coincidence is something this paper does not pursue. 


\section{The Theory of Value and Money}

\section{i. The labour theory of value}

Marx began his account of value theory in terms of the commensurability of commodities. Through their different properties, commodities are useful, or have use-value, and these use-values are realised in consumption. Commodities also are bought and sold; they exchange against other commodities in determinate proportions and hence have exchange-value. Marx argued that that this exchange-value is a form of appearance of value, and that what gives commodities value is that they are all products of labour.

In a society based on private property, the various heterogeneous labouring activities are private, separated from one another, employed in particular production processes. As such, an individual commodity is merely the objectification of the labour of its own particular production process, and is not representative of objectified labour in any general sense. If they are to be commensurated, heterogeneous commodities must express their value in something that is different from each of them, yet common to all of them. Then the value of a commodity can be expressed through its exchange with another commodity, hence in the physical form or use-value of that commodity. This is achieved as social development singles out one commodity to act as equivalent of the values of all other commodities. The particular value objectified in any commodity is thereby completely separated from that commodity and obtains an independent and homogeneous form of appearance as a sum of money. 27

27 It might be objected that it is pure transcendental idealism to derive exchange-value from value as its money-form in terms of a process whereby the opposition between use-value and value, contained within the commodity, is externalized as an opposition between commodities and money. Part of the point of this paper is to suggest why Marx as a materialist could legitimately adopt such a procedure. 
Marx argued that this was not a contingent but a necessary form of appearance of value in societies in which the means of production are privately owned. ${ }^{28}$ For all the labour processes of society are then separate and private, and it is the market which compares them and decides which labouring activity is to count and for how much: profitability determines (a posteriori) which private labours in fact have a social validity. But the market does not directly compare different labour processes; it rather compares quantitatively the difference between the commodity outputs and the commodity inputs of labour processes. To make such comparisons between heterogeneous commodities, they must be commensurated through their expression in one particular commodity that directly represents their value-equivalence to all other commodities. Money is thus the "universal equivalent'. Consequently, human labours are commensurated by means of the commensuration of commodity values as amounts of money, and the measure of abstract labour (in terms of its duration, i.e. 'socially necessary labour-time') appears as a quantitative money-value relation between commodities.

\section{ii. Commodity fetishism}

Marx drew several consequences from this. In the first place, because the only way in which private labour can become social is through the successful sale of its commodity output, then the social character of this private labour must be read from the product of labour as its objective characteristics qua commodity. Hence the social relations between producers (comprising the relation between the private labour of a particular production process and the total labour of society) take on a form of existence that appears to be quite external to the producers themselves,

28 This argument applies whether society is characterized by 'simple commodity production', with a relatively equal distribution of means of production across the population, or whether by 'capitalist production', in which the means of production are monopolized, thereby forcing those deprived of such ownership into labour markets as the only means of access to as a livelihood. But Marx's argument was that only in the latter type of society do the means of production become 'capital'. 
and instead intrinsic to inanimate commodities. Thus Marx drew attention to "the definite social relation between men themselves which assumes here, for them, the fantastic form of a relation between things", calling it "the fetishism which attaches itself to the products of labour as soon as they are produced as commodities" (Capital I, p.165). Elsewhere, Marx called this fetishism "the semblance of objectivity possessed by the social characteristics of labour" (ibid. p.167) and talked of money as the

"finished form of the world of commodities ... which conceals the social character of private labour and the social relations between the individual workers, by making those relations appear as relations between material objects, instead of revealing them plainly." (Ibid. pp.168-9.)

Secondly, class relations appear as individual relations. The social relations which separate labour from means of production, and thereby force people into the market to sell labour-power as the only way of gaining access to means of subsistence, are class relations. But because the wage appears to be the price of labour rather than the price of labour-power, all labour appears to be paid for. ${ }^{29}$ Since it is the payment of a wage that allows the worker access to the market for means of livelihood, then a class relation of dependence "is veiled by the commodity-form of the product and the money-form of the commodity" (ibid. p.713). For in the market, juridical equals exchange products with one another, and the class relations of dependence in production are thereby collapsed into a world of individual relations of independence in exchange.

Accordingly, the social relations of capitalism appear as something different from what they really are. Historically particular social situations are collapsed into universalised natural ones as relations

29 For Marx, "the form of appearance" of the wage contract renders "the actual relation invisible" and is "the precise opposite of that relation"; yet it is this appearance which grounds notions of justice and illusions of freedom in capitalist society. This was for him of "decisive importance" (Capital 1, p.680.) 
between producers appear as the objective characteristics of commodities, and class relations of production between worker and capitalist take the form of individual relations of the market-place: between consumer and commodity, and between employee and employer. Marx called this the "personification of things and reification of the relations of production", in "the bewitched, distorted and upside-down world haunted by Monsieur le Capital and Madame la Terre" (Capital III, p.969). In this manner, generalised commodity exchange forces a disjuncture between capitalist social relations and the way in which they appear, such that theory is required, both to set against the (real) appearances and to account for why those appearances take precisely the forms that they do. 30

In his analysis, Marx drew a parallel with religion (Value-Form p.22, Capital I pp. 163, 165): the artefacts created by the religious mind are worshipped as though they had an independent existence with creative powers over all animate beings and inanimate things. Hence God becomes the subject of creation and human beings the object. Subject and object are thereby rather obviously inverted. Marx's argument however, was that the same inversion of subject and object is generated by the separation of the producers from their means of production, and hence the separation of the producers from the products of their labour. ${ }^{31}$ In contrast to the case of religion, this real inversion, upon which capitalist material reality is founded, is not so obvious. Marx's path to it was through his analysis of money.

30 This theme is emphasized by Geras (1971).

31 For example,

"at the level of material production, of the life-process in the realm of the social - for that is what the process of production is - we find the same situation that we find in religion at the ideological level, namely the inversion of subject into object and vice versa..." (Capital I, p.990)

The quotation is from his Results of the Immediate Process of Production, reprinted as the appendix to the Penguin Capital I. 


\section{Money in a Capitalist Society}

In June 1867, Engels wrote to Marx commenting on the page-proofs he had just read of what was to become Volume I of Capital, and regretting the way in which Marx had treated the relationship between value and value-form. In his reply, Marx explained that he had added an appendix

"in which I set out the same subject again as simply and as much in the manner of a school text-book as possible . . . the issue is crucial for the whole book." (MECW 42, p.384.)

In this appendix (Marx 1994) ${ }^{32}$, Marx contrasted the material form of a commodity (its use-value) with its social form (its value-form). Value is expressed in the relation of one commodity to another; in such a relation there are always two forms of value: the commodity whose value is expressed (the relative form of value) and the commodity in which that value is expressed (the equivalent form of value). Neither form can exist without the other, while at the same time each form excludes the other. As regards the relative value-form, Marx argued that the value of a commodity acquires in exchange an independent form that acts as "the mirror of its own existence as value" (Value-Form, p.15), for the exchange relation reduces different kinds of labour to their common property as embodiments of abstract labour. But for the commodity in equivalent form the situation is rather different, for its own material form is immediately the value-form of the other commodity and is exchangeable for it. This reflection led Marx to his discussion of what he called the "peculiarities" of the equivalent form (Value-Form p.17ff, Capital I p.148ff.).

Four such peculiarities are discussed by Marx in this appendix, of which the first three are relevant here; first, that use-value appears as value; second, that concrete labour appears as abstract labour; and third, that private labour appears as social labour. ${ }^{33}$ In each of these peculiarities, the

32 The appendix was dropped from the second edition of Capital I, its contents being absorbed by the third and fourth sections of a rewritten first chapter.

33 The fourth peculiarity was that the fetishism of the commodity-form is more striking in the equivalent than in the relative form of value. 
appearance is the opposite of what is 'really' the case. Consider for example how concrete labour appears as abstract labour. A commodity expresses its value in another commodity, the latter being the equivalent form of value. Which commodity is in the equivalent form does not here matter, but whichever it is, it expresses the value of the commodity that is in relative form and thereby expresses the materialisation of abstract labour. However, because the equivalent is a particular commodity, its bodily form remains the product not of abstract labour but of some particular labour process. Yet that bodily form is nevertheless the form of appearance of abstract labour. Marx then remarked,
"Within the value-relation and the value expression included in it, the abstractly general counts not as a property of the concrete, sensibly real; but on the contrary the sensibly- concrete counts as the mere form of appearance or definite form of realisation of the abstractly general." (Value-Form p.18.)

The labour, that is, which is embodied in the equivalent, does not possess the general property of being human labour; the opposite is the case: representing human labour is the essence of the equivalent, and the specific particular labour which produced the equivalent counts only as the form of appearance of this essence.

"This quid pro quo is unavoidable because the labour represented in the product of labour only goes to create value insofar as it is undifferentiated human labour, so that the labour objectified in the value of a product is in no way distinguished from the labour objectified in the value of a different product. ...This inversion (Verkehrung) by which the sensibly-concrete counts only as the form of appearance of the abstractly general and not, on the contrary, the abstractly general as property of the concrete, characterises the expression of value. At the same time, it makes understanding it difficult. If I say: Roman Law and German Law are both laws, that is obvious. But if I say: Law (Das Recht), this abstraction (Abstraktum) realises itself in Roman Law and in German Law, in these concrete laws, the interconnection becomes mystical." (Ibid. p.18-19.) 
Once the universal equivalent form becomes identified with the natural form of some particular commodity, then it appears that the money-commodity has the natural property of being immediately exchangeable with all other commodities. The reason why a commodity such as gold becomes money is that all other commodities express their values in it; but what appears to be the case is that all other commodities express their value in gold because it is money. ${ }^{34}$ Money is then directly the form of appearance of abstract labour, of labour in general; it is abstract labour hypostatised as a concrete particular. ${ }^{35}$ Rosenthal summarises the argument in the following way:

"Earlier we remarked on the curiosity of Hegel's presenting the sun as the empirical universality of its satellites, and we have commented at length on the mystification wrought by his 'derivation' of the monarch as the empirical universality of the citizens of the state. Yet the proposition that money is the empirical universality of commodities, is neither curiosity nor mystification. It is correct.” (Rosenthal 1998, p.188.)

Commodities are reduced through exchange to quanta of abstract labour, and abstract labour is materialised in that commodity which serves as the universal equivalent.

One objection to this approach is that it appears to depend on a commodity notion of money. The 'peculiarity' that the particular labour which produces money comes to represent labour in general, or abstract labour, does appear to require that some labour be expended in the production of money. When labour is required to mine gold, there is no difficulty. But gold was soon replaced with symbols of itself, first, a contemporaneous representation in paper notes, and then an intertemporal representation in a variety of credit instruments, which themselves came to be traded in financial markets. And the twentieth century has seen an evolution of the quantity of those symbols which is independent of any underlying commodity-money backing.

34 See Marx in Capital I, p.187. 
Foley $(1983,1998)$ has suggested that one way to make sense of this historical evolution in a way that preserves the insights of a labour theory of value is to think of the value of money not at the individual but at the aggregate level. The value of money is not then the socially necessary labour time required to produce a unit of it, but the ratio at any time of the quantity of value-producing labour performed in society as a whole to the net output in price terms produced by that society. Such a definition must hold anyway in a commodity-money society, and to define it as holding when money is no longer a produced commodity is merely to state a labour theory of value at the aggregate level.

Some historical content is given to the definition with the argument that gold and foreign currency reserves are now only a part of the asset/liability structure of the modern capitalist state. Rather than the state managing some relationship between credit (including note issue) on the one hand and reserves of gold on the other, as in a quantity theory of money, it is the assets of the state more generally that underpin the quantity of credit. Hence this approach throws into relief the financing of state debt by the tax-raising powers of the state, the determination of this latter by the requirements of profitable accumulation, and speculation in financial markets over the valuation of that debt (via arbitrage with other financial assets) in the face of uncertainty over future profitability and the future tax revenues of the state. Hyperinflations are then generally associated with the disintegration of political authority such that the backing of state debt with future tax revenues becomes highly problematic; there is a collapse of the value of money and the temporary creation of a number of particular equivalents that can act as money. Conversely, deflations have been a major way in which profitability is restored by the large-scale devalorization of stocks of fixed capital, one part of the process being a flight out of physical assets and into the liquidity of

35 It is this which Rosen (1996) misses in his otherwise powerful critique, which then allows him to conclude that the Marxian account requires an ontological commitment to an Hegelian selfrealizing reproduction that is incompatible with Marxism's claim to be scientific. 
cash as the value of money rises. Money accordingly remains a hypostatised form of appearance of value in general, but the argument is based on aggregate rather than individual relations between value and price.

\section{Concluding Remarks}

This paper has argued two related propositions. First, the hypostatization of the abstract and general in the concrete and particular is a logic that is characteristic of ideology in general, and distinguishes it from science. Second, the logic of the market, the hypostatization of value in money, is a real process that inverts the relation between the general and the particular, and in so doing generates the reifications of commodity fetishism wherein class dependence is dissolved into seeming individual independence. It is this dual logic of hypostatization that renders economics so prone to slippage into an ideology.

For example, according to the labour theory of value, commodities only have value because they are produced: value is an attribute of produced commodities, which is materialised on their sale. But this entails a characteristic inversion. For it does not appear to be the case that commodities have value because they are produced; rather, what appears to be the case is that commodities are produced because they have value. It is this appearance which motivates 'subjectivist' theories of value, and exchange relations and consumer sovereignty thereby substitute for production relations and class struggle. In such a world, there is no focus on the ownership and control of the means of production. Rather, capital can hire labour or labour capital indifferently; it is a matter of choice whether money is invested or spent on consumer goods, freedom and equality rule, and the thrifty are rewarded with wealth and the profligate with poverty.

Yet the inverted world that is created as a mental act by this focus on circulation is not a simple epistemological mistake, because the real world of circulation is itself characterised by 
ontologically real processes of hypostatization. The hypostatizations of the theory have a material basis in the inversions produced by circulation as it actually is. And as abstract labour is hypostatised as money, so historically specific social relations appear in hypostatised form as ahistorical, universal and natural. Against this ideological background, the individualism of the market and the labour contract 'interpellates' individuals as subjects, and this enables a representation to individuals of an imaginary relation between them and their real conditions of existence. ${ }^{36}$ But not wholly imaginary, since commodity circulation is a real process.

Yet a further inversion should finally be mentioned. While the forgoing argument is based upon interpreting the sequence 'commodity-value-money' as a logic of hypostatization of the general in the particular, the derivation from commodity to money and thence to capital is also a derivation of the general from the particular. This is because commodity and money are not only historical prerequisites for the existence of capital; they are also its contemporary results. For the emergence of capital out of money and money out of commodity are long-gone historical processes. In today's world, commodity and money are forms of capital, its results rather than its preconditions. But to pursue this further, to investigate the conditions under which commodities (including the capacity to work) are forms of capital, how the social productive powers of labour are continually reified into the properties of capital, and how those properties develop through time, is to go a long way beyond the scope of this paper.

36 The formulations that ideology represents the imaginary relationship of individuals to their real conditions of existence, and that in this the process of interpellation is critical, are due to Althusser (1971, p.162ff). 


\section{References}

Althusser, L. (1971), Lenin and Philosophy and Other Essays. New York: Monthly Review Press.

Barrett, M. (1991), The Politics of Truth. Cambridge: Polity Press.

Blanchard, O.J. (1997), 'Is There a Core of Usable Macroeconomics?' American Economic Review: Papers and Proceedings 87.2 May: 244-46.

Blanchard, O.J. and S. Fischer (1989), Lectures on Macroeconomics. Cambridge Mass. and London: MIT Press.

Blaug, M. (1992), The Methodology of Economics: or How Economists Explain. Second Edition. Cambridge: Cambridge University Press.

Blinder, A.S. (1987), 'Keynes, Lucas, and Scientific Progress.' American Economic Review: Papers and Proceedings 77.2 May: 130-36.

Bliss, C.J. (1975), Capital Theory and the Distribution of Income. Amsterdam: North-Holland.

Colletti, L. (1972), From Rousseau to Lenin. London: New Left Books.

Colletti, L. (1973), Marxism and Hegel. London: New Left Books.

Colletti, L. (1975a), “Introduction”. Karl Marx: Early Writings. Harmondsworth: Penguin.

Colletti, L. (1975b), “Marxism and the Dialectic”. New Left Review 93, September-October: 3-29.

Dixit, A.K. (1977), 'The Accumulation of Capital Theory.' Oxford Economic Papers 29.1: 1-29.

Dobb, M. (1940), Political Economy and Capitalism. Second Edition. London: Routledge and Kegan Paul.

Eagleton, T. (1991), Ideology. London: Verso.

Foley, D. (1975), "Problems vs. Conflicts: Economic Theory and Ideology". American Economic Review: Papers and Proceedings 65.2, May: 231-6.

Foley, D. (1983), “On Marx’s Theory of Money”. Social Concept 1.1: 5-19. 
Foley, D. (1990), “Recent Developments in Economic Theory”. Social Research 57.3, Fall: 666687.

Foley, D. (1998), ‘Asset Speculation in Marx’s Theory of Money’. In R. Bellofiore (ed.), Marxian Economics: A Reappraisal. Essays on Volume III of Capital. Volume 1. Basingstoke: Macmillan.

Geras, N. (1971), 'Essence and Appearance: Aspects of Fetishism in Marx's Capital.' New Left Review 65 January-February: 69-85.

Hahn, F.H. (1984), Equilibrium and Macroeconomics. Oxford: Basil Blackwell.

Hausman, D.M. (1989), 'Economic Methodology in a Nutshell'. Journal of Economic Perspectives 3.2: $115-127$.

Hausman, D.M. (ed.) (1994), The Philosophy of Economics. Second Edition. Cambridge: Cambridge University Press.

Kirman, A.P. (1992), 'Whom or What Does the Representative Individual Represent?' Journal of Economic Perspectives, 6(2): 117-136.

Kreps, D.M. (1990), A Course in Microeconomic Theory. Hemel Hempstead: Harvester Wheatsheaf.

Lucas R.E. (1977), 'Understanding Business Cycles'. In R.E. Lucas, Studies in Business-Cycle Theory. Oxford: Basil Blackwell, 1981.

Marx, K. (1973), Grundrisse. London: Allen Lane.

Marx, K. (1976), Capital Volume I. Harmondsworth: Penguin.

Marx, K. (1981), Capital Volume III. Harmondsworth: Penguin.

Marx, K. (1994), The Value-Form. In S. Mohun (ed.), Debates in Value Theory. Basingstoke: Macmillan, 1994. 
Marx, K. and F. Engels (1975 onwards), Collected Works. London: Lawrence and Wishart. Referenced as MECW in the text.

Mas-Colell, A., M.D. Whinston and J.R. Green (1995), Microeconomic Theory. New York and Oxford: Oxford University Press.

McCloskey, D.N. (1985), The Rhetoric of Economics. Brighton: Wheatsheaf.

McCloskey, D.N. (1994), Knowledge and Persuasion in Economics. Cambridge: Cambridge University Press.

Rosen, M. (1996), On Voluntary Servitude: False Consciousness and the Theory of Ideology. Oxford: Polity.

Ruben, D-H. (1977), Marxism and Materialism. Hassocks: Harvester Press.

Sims, C.A. (1996), 'Macroeconomics and Methodology.' Journal of Economic Perspectives, 10(1): 105-120.

Solow, R.M. (1997), 'Is There a Core of Usable Macroeconomics We Should All Believe In?' American Economic Review: Papers and Proceedings 87.2 May: 230-32.

Stiglitz, J.E. (1994), Whither Socialism? Cambridge, Mass. and London: The MIT Press.

A. Tversky, P. Slovic and D. Kahneman (1990), 'The Causes of Preference Reversal'. American Economic Review: 80.1 March: 204-217. 